Federal Reserve Bank of Minneapolis

Research Department Staff Report 188

March 1995

\title{
On Sunk Costs and Trade Liberalization in Applied General Equilibrium
}

\author{
Jean Mercenier \\ Federal Reserve Bank of Minneapolis \\ and Université de Montréal
}

Nicolas Schmitt

Simon Fraser University

\begin{abstract}
We argue that the rationalization gains often predicted by static applied general equilibrium models with imperfect competition and scale economies are artificially boosted by an unrealistic treatment of fixed costs. We introduce sunk costs into one such model calibrated with real-world data. We show how this changes the oligopoly game in a way significant enough to affect, both qualitatively and quantitatively, the outcome of a trade liberalization exercise.
\end{abstract}

Any views expressed here are those of the authors and not necessarily those of the Federal Reserve Bank of Minneapolis or the Federal Reserve System. 


\section{Introduction*}

In the past decade, many traditional trade policy issues have been reformulated in terms of oligopoly models with increasing returns to scale borrowed from the industrial organization literature. An exciting portion of this research program aims to quantify and test the empirical relevance of some of the propositions of the new trade theory using numerical general equilibrium (GE) models calibrated with real-world data. Since Harris' (1984) seminal contribution, applied GE models with imperfect competition and scale economies have been extensively used, particularly to study trade liberalization issues. ${ }^{1}$ The role these models have played in the recent debates on the Canada-U.S. free-trade agreement, the North American Free Trade Agreement (NAFTA), and the European Single Market demonstrates their potential importance for policy analysis.

Previous applied GE modeling efforts, however, follow Harris in making the Chamberlinian assumption of costless entry and exit of firms into and out of an industry. This hypothesis is not particularly appealing. The importance of sunk costs in the shaping of market organization has long been investigated in the industrial organization literature.

* The authors are most grateful to two anonymous referees for their constructive comments that have led to significant improvements in the paper. They also thank Rick Harris, Bill Schworm, and seminar participants at the Federal Reserve Bank of Minneapolis for useful discussions and Antoine Pradayrol for computational assistance. Mercenier gratefully acknowledges hospitality from the Federal Reserve Bank of Minneapolis and financial support from the FCAR of the Government of Quebec and the SSHRC of the Government of Canada. Schmitt acknowledges hospitality from CERGE-EI, Charles University, and financial support from the Swiss National Fund for Scientific Research. Any views expressed here are those of the authors and not necessarily those of the Federal Reserve Bank of Minneapolis or the Federal Reserve System.

1 See, for example, Cox and Harris (1985), Wigle (1988), Brown and Stern (1989), Markusen and Wigle (1989), Devarajan and Rodrik (1991), Gasiorek et al. (1992), de Melo and Roland-Holst (1994), Markusen et al. (1995), Mercenier (1995a). 
Empirical research (from Bain 1956 to Sutton 1991) has abundantly demonstrated the existence of sunk costs and documented their various forms. The commitment value of sunk costs has long fascinated industrial organization theorists, and models abound that show why and how rents are derived from the incumbency advantage. All this work suggests that the costless entry/exit assumption, though convenient, is an oversimplification, which means that current applied GE models are possibly missing important aspects of the competitive game.

This paper shows, in particular, that the zero-sunk-costs restriction is responsible for artificially large efficiency gains from trade liberalization in these models. The reason follows from Harris' (1984) treatment of fixed costs as being entirely recoverable. If fewer firms can produce the same pre-liberalization level of output with fewer fixed factors, then anything that forces a firm out of the market liberates resources that become available to the rest of the economy-hence producing potentially large efficiency gains and, in some models, large welfare gains. The introduction of sunk costs into applied GE models would temper these gains in two important ways. First, because sunk investments are firm-specific, they will actually not become available to other sectors when a firm exits. They are lost resources; rationalization of production has no effect on welfare. Second, a firm becomes committed to a market by its irrecoverable expenditures. Since sunk factors have no opportunity value, the firm will remain in the market as long as it earns positive rents from the sunk asset, regardless of the market rate of return on recoverable assets. The irreversibility of sunk investment decisions, therefore, causes hysteresis in the economy's industrial structure: firms 
that find it profitable to enter an industry because of a trade distortion may well find it profitable to remain in the industry once the distortion is removed. In this case, sunk costs act as an exit barrier. The industry rationalization mechanism does not operate, and the predicted efficiency and associated welfare gains will not materialize. Thus, Harris' (1984) strongly stated presumption that the introduction of noncompetitive market structure and scale economies in applied GE models necessarily sharply increases the gains from trade liberalization may actually not hold. The point is important to make since Harris' presumption is widely believed in both academic and policy circles: it has entered common wisdom.

The existence of sunk costs may also potentially affect the nature of the oligopolistic game once trade liberalization has been implemented. Indeed, with sunk costs, some collusion among incumbents becomes consistent with no entry. Sunk costs also act as an entry barrier. They make it more likely that, in order to recover some of the dissipated rents, producers that have survived the policy change will tacitly agree to raise their prices. Even if transitory, this effect can only further mitigate the gains from trade liberalization. This argument was used in the 1950s by Johnson (1957) in his discussion of the possible U.K. participation in the European Economic Community. Surprisingly, the argument has been totally absent from the quantitative evaluations of both NAFTA and the European Single Market.

This paper is a first attempt at departing from the Chamberlinian assumption in an applied GE model of trade and production. More specifically, we show how sunk costs may be introduced into a numerical model, formulated as a two-stage game, that recognizes imperfect competition, increasing returns to scale, and product differentiation at the individual 
firm level. First, we modify the model previously used by Mercenier (1995a,b) to study European integration issues. Then we show how the presence of sunk costs quantitatively and qualitatively affects the outcome of the trade liberalization exercise.

The paper is organized as follows. In section 2 , we provide a theoretical discussion of why the usual modeling of fixed costs is likely to overstate the gains from trade liberalization. In section 3, we outline the applied GE model and the trade experiment. We discuss calibration and computational issues in section 4 and simulation results in section 5. In section 6 , we conclude.

\section{Motivation and Illustration}

\subsection{Sunk vs. Recoverable Fixed Costs}

We first highlight why industry rationalization can produce artificially large welfare gains when fixed costs are assumed recoverable. Throughout this section we use a two-sector GE model borrowed from Markusen (1981) and Horstmann and Markusen (1986).

Consider a two-sector autarkic economy producing two consumption goods in the amounts $X$ and $Y$. There is a single production factor, competitively traded and in fixed supply $\bar{K}$. Amount $Y$ is competitively produced with $K_{Y}$ units of capital; this good serves as numeraire, and we choose the units so that $Y=K_{Y}$, which sets the rental price of capital to one. Amount $X$ is produced with $K_{X}$ by $n$ identical Cournot-Nash firms facing increasing returns to scale technologies. The cost structure of the individual firm is $F+c x$, where $F$ 
represents a fixed cost, $c$ is a constant marginal cost, and $x=X / n$. Observe that, in this economy, $K_{X}=n F+c X$. Prices are set by oligopolists to equalize marginal revenues and costs:

$$
p\left(1-\frac{1}{n \epsilon_{X}}\right)=c,
$$

where $p$ is the unit price of output and $\epsilon_{X}$ is the elasticity of market demand for $X$. Entering or exiting is costless for a firm, so $n$ is determined by the zero-profit condition. Households have homothetic preferences $U(X, Y)$ and maximize their utility subject to their budget constraint. The economy's resource constraint imposes that $K_{X}+K_{Y} \leq \bar{K}$.

We now undertake the thought experiment that this economy is integrated overnight with a strictly identical economy producing the same goods. As is well known, even though no trade actually occurs in this homogeneous goods case, each oligopolistic firm increases its production simply because its perceived demand is more elastic in the integrated market than in the autarkic equilibrium (Markusen 1981). Hence, $p$ falls and negative profits follow. The output expansion effect leads to exit of firms and to efficiency gains.

Figure 1 illustrates the role of the fixed cost in this process. There ABC is the production possibility frontier (PPF) in autarky, and the slope of $\mathrm{BC}$ is the ratio of marginal costs $c$ (signed). Here $\mathrm{AB}$ is equal to the total fixed cost $(n F)$ necessary to start the production of $X$ with $n$ firms. It represents both the opportunity cost of the fixed resources in terms of $Y$ and the number of units of capital that must be used in industry $X$ before production can start. With $\mathrm{E}$ as the autarkic equilibrium, the slope of $\mathrm{AE}$ is equal (in absolute value) to the average cost [since $\left.A C_{x}=K_{x} / X=(A-Y) / X\right]$ and thus to $p$. The difference between $p$ and 
$c$ depends on $n$ and $\epsilon_{X}$. After integration, the equilibrium (without trade) is at $\mathrm{F}$, and the movement from $\mathrm{E}$ to $\mathrm{F}$ can be decomposed in two steps: EG represents the output expansion effect of integration for a given number $n$ of firms, and GF captures the rationalization effect via the exit of firms. Economic integration shifts the $\mathrm{PPF}$ to $\mathrm{AB}^{\prime} \mathrm{C}^{\prime}$ because the exit of firms saves the recoverable resources devoted to the fixed part of their cost. This shift is behind Harris' (1984) large welfare gains from trade liberalization.

[Insert here Figure 1: Trade Liberalization Without Sunk Cost]

Observe that this process depends critically on the mobility of the entire capital stock. Assume, now, that $F$ is entirely sunk: the ex ante mobile factor becomes firm-specific as soon as it meets the fixed component. In Figure 1, AB now represents the amount of capital which, given $n$ firms, has been sunk in autarky. The autarkic and integrated equilibria must then be on the same PPF, that is, along ABC. Clearly, the welfare gains from trade liberalization are potentially much smaller here than when $F$ is recoverable.

This analysis assumes that the entire fixed component of costs is sunk, which is clearly unrealistic. We will now show that trade liberalization may not save any fixed resources even if the sunk share of fixed costs is small.

\subsection{Sunk Costs as Exit Barriers}

To establish the role of sunk costs as barriers to exit, we make the simplifying assumption that the sunk share $0<s<1$ of fixed costs is exogenous to the firm. We thus avoid all 
strategic considerations most often associated with irrecoverable investments and disregard specific sources of irreversibility as documented in the industrial organization literature. We do this without too much apology: we want to establish the potential importance of irreversibility by using a generic formulation which is tractable in a large-scale applied GE model..$^{2}$

Consider the entry decision of a firm conditional on entering an industry with $n-1$ other firms. Because the expected bankruptcy rate is assumed constant, the cost of acquiring one unit of sunk capital is proportional to that of recoverable assets. We further simplify the exposition by setting the risk premium to zero. ${ }^{3}$ The firm's entry decision is based on the condition that

$$
p x \geq c x+F
$$

where all variables are evaluated at their postentry equilibrium values. While operating, the firm has to pay its mobile factors at market prices. Rewards to the sunk assets are therefore determined residually in the amount $(p-c) x-(1-s) F$. Because sunk capital has zero

2 More sophisticated models of irreversibility can, of course, be found in the literature. For instance, Dixit (1980) shows how investments and capacity can be used to deter entry. Bagwell (1990) underlines the role of imperfect information in preventing entry when product quality matters. Farrell and Shapiro (1990) consider the role of advertising and other specific assets. See Gilbert (1989) for an early survey of this literature. Each of these models captures important features of some industries. However, all imperfectly competitive sectors may not fit in any one of these specific frameworks, as required for numerical tractability. Furthermore, the attractiveness of most of these models stems from their explicit treatment of intertemporal trade-offs, which one can hardly pretend to mimic in a static model. For these reasons, we do not allow firms to manipulate their incumbency advantage. It should be mentioned that a few attempts have recently been made to explicitly model irreversibility in international trade: Motta (1992) and Schmitt (1993) in models of horizontal and vertical differentiation, respectively, with explicit choice of product attributes and Horstmann and Markusen (1987) on multinationals.

3 As is immediate to check, the assumption is innocuous. It only avoids the trouble of rescaling some variables. 
opportunity returns, the firm's optimal behavior is to remain in the market as long as those rents are positive; the exit condition is now

$$
p x \leq c x+(1-s) F .
$$

Comparing (2) and (3) shows why sunk costs act as an exit barrier: by sunk investment decisions, firms commit themselves to stay in the market-and signal to potential entrants that they will do so-despite possible below-market-level returns for their specific assets.

Figure 2 illustrates how this market commitment affects the efficiency gains that result from our trade integration experiment. The PPF in autarky is now composed of three parts. Segments AB and BC represent, respectively, the economy's sunk ( $n s F)$ and recoverable $[n(1-s) F]$ fixed resources; the absolute value of the slope of segment $\mathrm{CD}$ is the marginal cost $c$ (signed).

\section{[Insert here Figure 2: Trade Liberalization With Sunk Cost]}

An autarkic equilibrium is shown at $\mathrm{E}$, where $p>A C_{x}>c$ since the average cost of an existing firm (in terms of mobile factors) is given by the slope of BE. No entry occurs since the entrant's average cost including the sunk cost (the slope of AE) is just equal to $p$. The differences among price, average cost, and marginal cost depend now not only on the demand elasticity and the number of firms, but also on the level of the sunk investment.

Here, as is true without sunk costs, integration induces firms to expand production and, hence, lower equilibrium prices. In Figure 2, a new equilibrium is shown at point G. Although the markup has fallen, $p^{\prime}>A C_{x}^{\prime}$ is given by the slope of $\mathrm{BG}$, and no exit occurs. 
The cost of the mobile factors is covered, and the owners of the sunk asset have no incentive to pull out since a smaller rent is preferred to no rent at all.

Clearly, the fixed costs do not need to be entirely sunk for trade liberalization to have no rationalization effect whatsoever. Indeed, if economic integration is not strong enough to prevent incumbents from earning some positive returns on their sunk assets, the rationalization mechanism will not operate. There will be neither efficiency nor welfare gains from rationalization.

\subsection{Sunk Costs as Entry Barriers}

As a comparison between equations (2) and (3) makes clear, a sunk expenditure also qualifies as a barrier to entry since it is a cost "which must be borne by a firm which seeks to enter an industry but is not borne by firms already in the industry" (Stigler 1968, p. 67). This shield against potential entrants will, in general, provide some scope for collusion among incumbents in the aftermath of a trade liberalization.

To see why, consider the profit-maximizing condition for a firm. The pricing equation can be rewritten as

$$
p\left(1-\frac{1+\phi}{n \epsilon_{X}}\right)=c,
$$


where $\phi$ is an index of collusion which was initially set to zero. This index can vary between $\phi=0$ (Cournot) and $\phi=n-1$ (perfect collusion). ${ }^{4}$ Since an incumbent firm's behavior influences an entrant's expected profit, the entry condition becomes

$$
p(\phi) x \geq c x+F
$$

where again all variables are evaluated at their postentry equilibrium values. We have written $p$ as a function of $\phi$ in order to stress the fact that, consistently with the symmetry assumption, the potential entrant is assumed to collude as well. Since a potential firm was at best expecting zero ex ante profit in the initial equilibrium and since trade liberalization has squeezed the operating profits of incumbents, the liberalization has a fortiori made entry unattractive; that is,

$$
p(\phi) x<c x+F, \quad \phi=0
$$

where all variables are evaluated at the post-liberalization, postentry equilibrium values with $\phi=0$. Clearly, some price increases are consistent with no entry. The incentive exists because collusion improves the returns on specific factors. In this sense, economic integration has created a scope for collusion among existing firms of which sunk costs are an indirect cause. The extent of tacit collusion determines the output expansion effect through $p^{\prime}$. Therefore, in Figure 2, the equilibrium, once existing firms have taken advantage of this scope for collusion, must be to the left of G along ACD. ${ }^{5}$

\footnotetext{
4 See Brander and Spencer (1985) for a similar formulation. Although $\phi$ is interpreted here as the degree of collusion, it is known as a conjectural variation. Recent advances in industrial organization (Dockner 1992, Lapham and Ware 1994) have established a mapping between the static conjectural variation and firms' behavior in dynamic games. These results imply that the scope for collusion among existing firms can indeed be viewed as the outcome of specific dynamic noncooperative games between firms.

5 The exact location of the equilibrium will, of course, depend on the elasticity of the firm's revenue with respect to $\phi, n$, and $p$.
} 
Collusion (tacit or explicit) may not last long. It may, nevertheless, be an important factor in shaping the economy in the aftermath of a trade liberalization. Merger waves, for instance, have often followed trade liberalization; these may be interpreted as attempts by factor owners to recoup lower returns on their specific factors by changing the competitive behavior within a subset of firms. Several recent models in the literature have indeed confirmed, using a repeated game framework, that economic integration may enhance tacit collusion. ${ }^{6}$ Modeling the process of collusion in a large-scale applied GE model is, however, presently beyond our reach because of computational difficulties. We, therefore, limit ourselves in our empirical investigation to the much more modest objective of providing an estimate of the scope for collusion and of the GE effects that would result if firms were to take full advantage of this scope.

The model of this section assumed homogeneous goods. This assumption is convenient because no trade actually results from trade integration. Yet trade integration causes an output expansion, and this expansion triggers the industry rationalization mechanism. Clearly, nothing in this chain mechanism depends on the homogeneity of goods. Indeed, Markusen (1981) and Horstmann and Markusen (1986) have shown that the output expansion still occurs when, as in our applied GE model, products are treated as imperfect substitutes, markets have different sizes, and the initial equilibrium involves nonprohibitive barriers to trade.

\footnotetext{
6 See Davidson (1984), Rotemberg and Saloner (1989), and Fung (1992). Fung (1992) shows, among other things, that the collusive outcome gets more likely when economic integration brings the cost of the foreign and the domestic firms closer together.
} 


\section{The General Equilibrium Framework and Numerical Experiments}

\subsection{An Overview of the Model}

We follow Sutton (1991) and assume that the new firm faces an indivisible setup (or transaction) cost upon entering, that is, net of any resale value: it constitutes an irrecoverable part of fixed costs. Its level plays no role in the producer's day-to-day pricing policy; sunk costs affect prices only indirectly by their influence on entry/exit decisions. The individual industry setting is a two-stage game. In stage 1, potential entrants choose whether or not to enter; in stage 2, firms compete in the output market. The payoff is either zero, if the firm decides not to enter, or the profits expected to be earned at stage 2 less the sunk cost incurred at stage 1 , if it decides to step in.

The second stage of the individual industry game is embedded in a general equilibrium, so that, though exogenous to the firm, the sunk costs are endogenous to the economy as a whole. The industry equilibrium is specified as stationary subgame-perfect. In that very specific sense, the static GE model can be interpreted as the steady state of a dynamic model. Note that the nature of the game and our assumption of an indivisible setup cost require that the number of firms be treated as an integer in the general equilibrium.

The GE setup has been extensively discussed by Mercenier (1995a,b). To conserve on space, we here give only an overview of its main features and refer to those papers for a more formal presentation. 
The world economy consists of six regions: Great Britain (GB), Germany (G), France (Fr), Italy (It), the rest of the European Economic Community (RE), and the rest of the world (ROW). All regions are fully endogenous and have the same structure. Each region has nine sectors of production, of which five are imperfectly competitive; see Table 1. The treatment of the competitive side of the model is quite standard. (See, for example, Srinivasan and Whalley 1986.) Regions are linked by an Armington system (in which goods are differentiated in demand by their geographic origin). In the oligopolistic sectors, firms-both existing and potential entrants-are assumed to be symmetric (they have the same technology and market shares) within national boundaries. Firms operate with fixed primary factor costs and, therefore, face increasing returns to scale in production. They have no monopsony power in any market for inputs, primary or intermediate.

[Insert here Table 1: Sectoral Disaggregation and Industry Characteristics]

Each individual oligopolist produces one differentiated good. The game between noncompetitive firms is Nash in sales. The instantaneous GE concept adopted is a compromise in terms of informational requirements between the primitive conjectural-Cournot-NashWalras equilibrium of Negishi (1961) and the objective-Cournot-Nash-Walras equilibrium introduced by Gabszewicz and Vial (1972). Namely, here noncompetitive firms know the preferences and technologies of their clients, which they use in maximizing profits. Firms are, however, assumed to neglect the feedback effect of their decisions on their profits via 
income (the Ford effect) and input-output multipliers [the Nikaido (1975) effect]. ${ }^{7}$

Final demand decisions are made in each region by a representative utility-maximizing agent. A detailed region- and sector-specific system of price-responsive intermediate demands is specified. All components of demand-final as well as intermediate-recognize differences in products from individual oligopolistic firms, à la Dixit and Stiglitz (1977) and Ethier (1982). Both preferences and technologies, therefore, have increasing returns to the number of varieties, so that product diversity affects not only household utility but also production efficiency in all sectors, competitive and noncompetitive. Production factors move freely across sectors, and capital is assumed internationally mobile as long as it has not been used to meet specific investments. National economies within Europe are initially assumed segmented in the sense that each firm treats the national markets as separate entities for which separate output decisions can be made; see, for example, Brander (1981). Market segmentation is caused by nontariff barriers—such as norms, government procurement policies, and security regulations-which prevent consumers from cross-border arbitraging. These nontariff barriers are treated as latent variables underlying the pre-reform price system, which is calibrated to be consistent with optimal output decisions by individual oligopolists.

\subsection{European Trade Integration}

The performed experiment portrays the move to a single market in Europe, as first

7 This partial equilibrium compromise obviously simplifies the computations. It has also been advocated in the theoretical literature (Hart 1985, p. 121) in order to avoid nonexistence problems highlighted by Roberts and Sonnenschein (1977). 
formalized by Smith and Venables (1988). It consists of forcing the individual firms to switch from a separate output decision for each market to a single output decision within Europe, where markups are determined from average EEC-wide monopoly power. The interpretation is that cross-border arbitraging is restored by the removal of all forms of nontariff barriers. Note that the experiment is similar to the one we did above, in the theoretical analysis.

Formally, the noncompetitive firm's markup equation in European markets (neglecting the industry subscript for convenience) is

$$
\frac{p_{i j}-v_{i}}{p_{i j}}=\lambda \frac{\partial \log p_{i j}}{\partial \log z_{i j}}+(1-\lambda) \frac{\partial \log p_{i E E C}}{\partial \log z_{i E E C}}, \quad j \in E E C .
$$

Here, $p_{i j}\left(p_{i E E C}\right)$ and $z_{i j}\left(z_{i E E C}\right)$ denote, respectively, the price and the volume of sales of country $i$ 's representative firm in national market $j$ (in the EEC-wide market), and $v_{i}$ is its marginal cost. The control parameter $\lambda$ is binary: the model is calibrated with $\lambda=1$, and market integration is implemented by setting $\lambda=0$.

\subsection{Post-Reform Equilibrium With Collusion}

To provide a quantitative assessment of the potential costs of increased tacit collusion induced by economic integration, we modify the post-reform, within-EEC output strategy of European firms and introduce a sector-specific real collusion index $\phi_{s} \geq 0$ as follows:

$$
\frac{p_{\text {isEEC }}-v_{\text {is }}}{p_{\text {isEEC }}}=\left(1+\phi_{s}\right) \frac{\partial \log p_{\text {isEEC }}}{\partial \log z_{\text {isEEC }}}, \quad i \in E E C .
$$

We start from the post-trade-liberalization Nash-Cournot equilibrium $\left(\phi_{s}=0\right)$ and compute the largest value of the tacit-collusion indices consistent with no entry in any industry. That 
is, we calculate the largest value such that at the new equilibrium, if in any industry a firm were to consider entering the EEC market, its operating profits would not cover the setup costs. In so doing, we remain consistent with our assumption of symmetry of domestic firms - actual and potential-in an industry and assume that the entrant joins incumbents in the tacit-collusion arrangement when evaluating its potential profits. In view of this simplification, our numerical experiment should be understood as providing an upper bound to the true scope for collusion.

\section{Calibration and Computational Considerations}

\subsection{The Calibration of the Nonsunk Component of Costs}

The calibration of the optimal markups does not depend on whether or not firms have sunk costs, so we do not dwell on this; see Mercenier (1995a). By that calibration we determine the initial price system $p_{i j}$ and the variable unit costs $c_{i}$; average prices are normalized to one.

When firms have no sunk costs, they earn no rents (or supranormal profits) in equilibrium, and the difference between average and marginal costs unambiguously determines the

fixed unit costs. Technologies have to be assumed region-specific in this case. When entry barriers exist, firms can earn positive oligopoly rents on their specific assets. Since data on base-year supranormal profits are unavailable or unreliable, we have to make some additional assumptions on the technology. We assume that, except for small differences in the 
way they combine variable inputs, firms have access to the same technology independently of their production location. ${ }^{8}$ They, therefore, face essentially the same amount of fixed costs, though they exploit unequally well economies of scale in the base year. In other words, if the composition of variable costs did not differ, all firms in an industry would be on the same average cost curve. The average cost curve is, then, pinned down by the assumption that the less efficient firms experience zero profits. ${ }^{9}$

We state this more formally. Assume that the representative firm of country $j$ has the smallest output $x_{j}$. The scale elasticity at which it operates is $1 / c_{j}$ (where average prices equal unity), and it earns no oligopoly rent, so its total fixed costs are

$$
F_{j}=c_{j} x_{j}\left(\frac{1}{c_{j}}-1\right)
$$

The more efficient producers' fixed costs are, then, determined so that were they to operate at the same scale as firm $j$ and produce $x_{j}$, they would face the same scale elasticities $1 / c_{j}$. For producer $i$,

$$
F_{i}=c_{i} x_{j}\left(\frac{1}{c_{j}}-1\right)
$$

Thus, were $c_{i}=c_{j}$, firms $i$ and $j$ would have the same fixed costs. It is then straightforward to compute the scale elasticities that firms face at their actual output level $x_{i} \geq x_{j}$, as well as the oligopoly rents they earn in the base-year equilibrium. Table 2 reports the computed

8 Expenditure shares on variable inputs are provided by the data base and are, therefore, not identical across countries within the same industry.

9 This somewhat arbitrary assumption is conservative. For reasons that should be clear from the previous section, assuming positive rather than zero profits for these firms in the base year would only strengthen our argument. 
inverse base-year scale elasticities for the five imperfectly competitive sectors in our data set. ${ }^{10}$

[Insert here Table 2: Calibrated Ratios of Marginal to Average Costs]

\subsection{The Calibration of Sunk Costs}

A general equilibrium with sunk costs supports nonzero supranormal profits without attracting entry. We determine the level of the setup costs to be the lowest possible consistent with no entry in the base year, that is, such that the expected profit of an entrant is zero in the most efficient country of production.

We do not expect, a priori, large differences in sunk costs across industrialized countries within an industry. To assume that entry barriers are of equal size in Europe and in the rest of the world proves unrealistic, however. This is because European firms typically operate at a smaller scale than do their competitors in the United States and Japan. Producers in the rest of the world, therefore, experience higher operating profits, which would make this region the most attractive location for new entrants. The size of the sunk costs necessary to prevent this entry is unreasonably high compared to the average European firm's size. Therefore, we allow a European-specific sunk cost as small as possible consistent with the same costs within an industry across all European countries and no entry.

10 Due to the lack of reliable data on the composition of fixed costs, we assume that, in each region, fixed and total costs have the same share of capital and labor inputs. 
Table 3 reports the calibrated sunk costs as a percentage of the representative firm's value of production in the five oligopolistic sectors. Empirical estimates of sunk costs are extremely scarce and, when available, refer to very disaggregated subindustries. Short of direct comparisons, we offer two remarks to put our estimates into perspective. First, the results in Table 3 are about 10 times higher than those estimated by Sutton (1991, Table 4.3, p. 106) for very specific sub-industries belonging to the food and beverages sector. Recall, however, that in the model this sector is approximated as perfectly competitive because of the very low concentration and economies of scale that prevail at our level of aggregation. We should not be surprised, therefore, that in those sectors that are more oligopolistic than is the food and beverages sector, our sunk cost estimates relative to sales are higher than Sutton's. Second, our estimates seem reasonable if we recognize that sunk costs in a given industry are proportional to the minimum efficient scale of production in that industry. (See Sutton 1991 for a discussion on this point). ${ }^{11}$

[Insert here Table 3: Calibrated Sunk Costs as Percentage of Representative Firm's Sales]

\subsection{Computational Considerations}

The computation of the subgame-perfect stationary two-stage equilibrium is made extremely complex by the integer nature of the entry/exit decision. Fortunately, interindustry differences in concentration and firm size are essentially identical across regions, which makes

11 Pratten (1988) reports minimum efficient scale (m.e.s.) for the food industries ranging from 0.2 percent to 1.2 percent of the U.K. market (with a few outliers around 4-5 percent). He estimates the m.e.s. in the chemical and the transportation industries as 20 percent and 100 percent of the U.K. market, respectively. 
the system almost recursive with respect to the number of firms. Recognizing this consid-

erably reduces the computational work. ${ }^{12}$ The numerical search is nevertheless extremely tedious, excessively so to permit any serious numerical exploration of the possibility of multiple solutions. Therefore, nothing ensures that the equilibrium found is independent of the search strategy adopted. Progress in nonlinear mixed-integer programming algorithms must be made before such issues can be explored in large-scale highly nonlinear applied GE models of this type. ${ }^{13}$

\section{Results}

In Table 4, we compare the trade integration results generated with the traditional costless-entry, zero-profit equilibrium concept to those obtained when acknowledging entry barriers in the form of sunk costs; in both cases, the output game is Nash. All results are percentage deviations from initial equilibrium. To conserve on space, we report only the three variables most relevant to our discussion: welfare, the number of firms, and the efficiency gains measured as the real cost savings due to increased scale of production. ${ }^{14}$

[Insert here Table 4: Effects of European Trade Integration Without Collusion]

12 This is our strategy: Sort industries by decreasing concentration. Determine the smallest integer number of firms in the most concentrated sector consistent with nonnegative profits and no entry while holding constant industry structure elsewhere. Proceed in the same way for the next most concentrated industry; then check that the equilibrium number of firms previously computed is still consistent with nonnegative profits and no entry. If not, move back and adjust; otherwise, proceed forward to the next industry.

13 Mercenier (1995b) suggests that costless entry/exit of firms is a potentially important cause of multiplicity in applied GE with increasing returns to scale and imperfect competition. His conjecture suggests that nonuniqueness is less likely to be a problem in the present model.

14 In order to reduce the numerical burden, we treat the number of firms as a real rather than an integer variable when computing the costless-entry, zero-profit equilibrium. This assumption is clearly conservative: it can only bias downward the importance of the industry rationalization mechanism in the costless exit case. 
As is clear in section a of the table, without sunk costs, trade liberalization results in unambiguous efficiency gains. Industry rationalization à la Harris (1984) is seen here to operate as a powerful mechanism. It is particularly apparent in the office machinery sector, which provides a textbook illustration: Trade barriers within the EEC are responsible for the existence of an excessive number of small inefficient firms in all regions; across regions, the opening up of trade forces from 5 to 15 percent of the producers out of the market, hence letting the survivors increase their output and move down along their average cost curves. There is, however, no reason why prices should go down uniformly across regions within an industry: the restructuring of demand may actually increase the market size of some regions' producers at the expense of some others. This is what we observe, for instance, in the motor vehicles sector where, in some regions, the average firm size increases, generating efficiency gains despite new entries occurring. Clearly, costless entry/exit of firms is key in initiating this efficiency-improving reallocation of production factors across regions and industries.

Sunk costs, by specializing some factors and by altering the nature of the game, make the rationalization gains more unlikely. Section b of Table 4 demonstrates this. Protected from potential competitors by entry barriers, all but the least efficient producers earn positive rents: the policy-induced contraction of price-cost margins is too small in most regions and industries to induce exit. ${ }^{15}$ The industry structure thus remains essentially unaffected by

15 Exit actually only occurs where rents were arbitrarily assumed null in the initial equilibrium; an assumption of positive profits for the least efficient producers might have resulted in no exit at all. 
trade liberalization. The small efficiency gains that result are, in all but very few cases, exclusively due to the price-induced expansion of demand. ${ }^{16}$

We have shown that the presence of sunk costs fundamentally affects the trade policy outcome because the industry rationalization mechanism is inoperant with sunk costs. Yet, surprisingly, the welfare gains seem here quite robust to these differences. The reason behind this is plain, however. Consumers and producers-both noncompetitive and competitivevalue product diversity à la Dixit-Stiglitz-Ethier. The efficiency gains that result from rationalization without sunk costs are, with this particular parameterization, offset by the cost of having fewer products made available to final and intermediate demands. Clearly, this need not be true in other differently parameterized models where industry rationalization does generate welfare gains.

[Insert here Table 5: Effects of European Trade Integration with Tacit Price Collusion]

Are we right to assume that the output game remains unaffected by the trade reform? Or should we rather consider the possibility that, in Johnson's (1957, p. 271) words, "division of markets by trade barriers ... may simply be replaced by international cartelization having the same effect"? The results in Table 5 suggest that in some industries, firms have indeed significant incentives to collude in order to recover some of their pre-reform rents. As one expects, the scope for collusion is highest in the most concentrated industries: motor vehicles

\footnotetext{
16 Aggregate EEC output unambiguously increases in all noncompetitive sectors although substitution effects may result in some producers gaining and others losing market shares. Note that this, together with changes in variable unit costs, is sufficient to attract some entry in the German nonpharmaceutical chemical industry: as one expects, the sunk costs are small in this sector as a result of low industry concentration.
} 
and office machinery. In these sectors, EEC producers could collectively raise their prices by some 16 and 28 percent, respectively, without attracting entry. In the other three noncompetitive sectors, the large number of competitors present in the market (indirectly, through lower levels of sunk costs) prevent existing firms from entering into a collusive arrangement of serious importance. Overall, however, the general equilibrium effects prove sufficient to offset most of the efficiency and welfare gains expected from the trade reform: the initial segmentation of the EEC market by nontariff barriers is replaced by inter-European tacit collusion having almost the same effect. The outcome could actually become much worse if products were slightly more differentiated than is assumed in the base scenario, as the sensitivity analysis reported in Table 6 indicates. Though the welfare gains prove reasonably robust when European firms do not collude, the gains turn unambiguously into losses when European firms collude in a world with slightly more differentiated products. Then, ironically, the only ones to benefit from the completion of the European Single Market are consumers in the rest of the world.

[Insert here Table 6: Welfare Gains - Sensitivity Analysis]

\section{Conclusions}

A major conclusion of recent research in industrial organization is that the structure of noncompetitive industries is largely conditioned by the existence of sunk costs. Yet, so far, the literature on applied imperfectly competitive GE models has not modeled these costs. Here we have shown how a generic formulation of sunk costs can be introduced into a static 
large-scale model of trade and production calibrated on real-world data. The GE concept adopted is consistent with free entry and exit of firms as well as pure profits (or rents on specific assets). It encompasses the traditional Chamberlinian zero-profit equilibrium as a special case, where sunk costs are null.

We have shown that adopting the broader GE concept has important implications for the evaluation of trade liberalization policies. One is that Harris' (1984) treatment of fixed costs as entirely recoverable is likely to generate artificially large efficiency gains, and in some models large welfare gains, from industry rationalization. Another implication of the introduction of sunk costs is that, protected against potential competition by entry barriers, incumbent firms have an incentive to collude to recover some of their forgone rents. This can only further mitigate the gains to be expected from trade liberalization. Our main conclusion is clear. When a model includes sunk costs, Harris' presumption that incorporating imperfect competition and scale economies necessarily sharply increases gains from freer trade appears ill-founded and possibly misleading. Since this presumption is so strongly stated and widely believed in the literature, we think that our point is important. Admittedly, our formalization of both sunk costs and collusion is rather crude. A more satisfactory treatment of irreversibility would require an explicit modeling of agents' intertemporal decision making, presumably under uncertainty. Also, the modeling of collusion must address the free-rider incentive of the participants in order to determine how long such an arrangement might be sustainable. Game-theoretic dynamic extensions are called for here. The aim of 
this first attempt to incorporate sunk costs in a large-scale applied GE model should, therefore, be seen as providing quantitative evidence that more theoretical and empirical research on the industrial organization effects of trade policy is needed. The recent work by Dixit and Pindyck (1994) suggests that progress in that direction is possible-indeed, promising. Though our discussion has focused on trade policy issues, the implications are evidently much more general. 


\section{References}

Bagwell, Kyle (1990), "Informational Product Differentiation as a Barrier to Entry", International Journal of Industrial Organization, 8, 2, 207-23.

Bain, Joe S. (1956), Barriers to New Competition, (Cambridge, Mass.: Harvard University Press).

Brander, James A. (1981), "Intra-Industry Trade in Identical Commodities", Journal of International Economics, 11, 1-14.

Brander, James A. and Barbara J. Spencer (1985), "Tacit Collusion, Free Entry, and Welfare", Journal of Industrial Economics, 33, 3, 277-94.

Brown, Drusilla K. and Robert M. Stern (1989), "U.S.-Canada Bilateral Tariff Elimination: The Role of Product Differentiation and Market Structure", in R.C. Feenstra (ed.), Trade Policies for International Competitiveness, (Chicago: University of Chicago Press), 217-253.

Cox, David and Richard Harris (1985), "Trade Liberalization and Industrial Organization: Some Estimates for Canada", Journal of Political Economy, 93, 115-45.

Davidson, Carl (1984), "Cartel Stability and Tariff Policy", Journal of International Economics, 17, 219-37.

Devarajan, Shantayanan and Dani Rodrik (1991), "Pro-competitive Effects of Trade Reform: Results From a CGE Model of Cameroon", European Economic Review, 35, 5, 11571184.

Dixit, Avinash (1980), "The Role of Investment in Entry-Deterrence", Economic Journal, 90, March, 95-106.

Dixit, Avinash K. and Robert S. Pindyck (1994), Investment Under Uncertainty (Princeton, N. J.: Princeton University Press).

Dixit, Avinash K. and Joseph E. Stiglitz (1977), "Monopolistic Competition and Optimum Product Diversity", American Economic Review, 67, 297-308.

Dockner, Engelbert J. (1992), "A Dynamic Theory of Conjectural Variations", Journal of Industrial Economics, 40(4), 377-95.

Ethier, Wilfred J. (1982), "National and International Returns to Scale in the Modern Theory of International Trade", American Economic Review, 72, 389-405.

Farrell, Joseph and Carl Shapiro (1990), "Asset Ownership and Market Structure in Oligopoly", Rand Journal of Economics, 21, 2, 275-92. 
Fung, K.C. (1992), "Economic Integration as Competitive Discipline", International Economic Review, 33, 4, 837-47.

Gabszewicz, Jean J. and Jean-Pierre Vial (1972), "Oligopoly 'à la Cournot' in a General Equilibrium Analysis", Journal of Economic Theory, 4, 381-400.

Gasiorek, Michael; Smith, Alasdair and Anthony J. Venables (1992), "1992: Trade and Welfare; a General Equilibrium Model", Centre for Economic Policy Research Discussion Paper 672, London, March.

Gilbert, Richard J. (1989), "Mobility Barriers and the Value of Incumbency", in Richard Schmalensee and Robert D. Willig (eds), Handbook of Industrial Organization, Vol 1, (Amsterdam: North-Holland), 475-535.

Harris, Richard (1984), "Applied General Equilibrium Analysis of Small Open Economies with Scale Economies and Imperfect Competition", American Economic Review, 74(5), 1016-32.

Hart, Oliver D. (1985), "Imperfect Competition in General Equilibrium: An Overview of Recent Work", in: Frontiers of Economics, K.J. Arrow and S. Honkapohja (eds.), (Oxford: Blackwell), 100-149.

Horstmann, Ig J. and James R. Markusen (1986), "Up the Average Cost Curve: Inefficient Entry and the New Protectionism", Journal of International Economics, 20, 225-247.

Horstmann, Ig J. and James R. Markusen (1987), "Strategic Investments and the Development of Multinationals", International Economic Review, 28, 109-21.

Johnson, Harry (1957), "The European Common Market: Risk or Opportunity?", Weltwirtschaftliches Archiv, 79, 267-80.

Lapham, Beverly J. and Roger Ware (1994), "Markov Puppy Dogs and Related Animals", International Journal of Industrial Economics, 12, 569-93.

Markusen, James R. (1981), "Trade and the Gains from Trade with Imperfect Competition", Journal of International Economics, 11, 531-551. Reprinted in, G. M. Grossman (ed.), Imperfect Competition and International Trade, (Cambridge (Mass.): MIT Press), Chap. 3, 1992.

Markusen, James R.; Rutherford, Thomas F. and Hunter, Linda (1995), "Trade Liberalization in a Multinational-Dominated Industry", Journal of International Economics, 38, $95-117$.

Markusen, James R. and Randall Wigle (1989), "Nash Equilibrium Tariffs for the United States and Canada: The Roles of Country Size, Scale Economies, and Capital Mobility", Journal of Political Economy, 97, 2, 368-86. 
Melo, Jaime de, and David Roland-Holst (1994), "Tariffs and Export Subsidies When Domestic Markets are Oligopolistic", in J. Mercenier and T.N. Srinivasan (eds), Applied General Equilibrium and Economic Development: Present Achievements and Future Trends, (Ann Arbor, Mich.: University of Michigan Press), 191-208.

Mercenier, Jean (1995a), "Can '1992' Reduce Unemployment in Europe? On Welfare and Employment Effects of Europe's Move to a Single Market", Journal of Policy Modeling, 17, 1-37.

Mercenier, Jean (1995b), "Nonuniqueness of Solutions in Applied General Equilibrium Models with Scale Economies and Imperfect Competition", Economic Theory, forthcoming.

Motta, Massimo (1992), "Sunk Costs and Trade Liberalization", Economic Journal, 102, $578-87$.

Negishi, Takashi (1961), "Monopolistic Competition and General Equilibrium", Review of Economic Studies, 28, 196-201.

Nikaido, H. (1975), Monopolistic Competition and Effective Demand (Princeton, N.J.: Princeton University Press).

Pratten, Cliff (1988), "A Survey of the Economies of Scale", Economic Papers No 67, October, European Commission.

Roberts, John and Hugo Sonnenschein (1977), "On the Foundations of the Theory of Monopolistic Competition", Econometrica, 45, 101-113.

Rotemberg, Julio J. and Garth Saloner (1989), "Tariffs vs. Quotas with Implicit Collusion", Canadian Journal of Economics, 22, 2, 237-244.

Schmitt, Nicolas (1993), "Equilibria and Entry in Two Interdependent Spatial Markets", Regional Science and Urban Economics, 23, 1-27.

Smith, Alasdair and Anthony J. Venables (1988), "Completing the Internal Market in the European Community: Some Industry Simulations", European Economic Review, 32, 1501-25.

Srinivasan, T.N. and John Whalley, eds. (1986), General Equilibrium Trade Policy Modeling, (Cambridge, Mass.: MIT Press).

Stigler, George J. (1968), The Organization of Industry, (Homewood, Ill.: R. D. Irwin).

Sutton, John (1991), Sunk Costs and Market Structure: Price Competition, Advertising, and the Evolution of Concentration, (Cambridge, Mass.: MIT Press).

Wigle, Randall (1988), "General Equilibrium Evaluation of Canada-U.S. Trade Liberalization in a Global Context", Canadian Journal of Economics, 21,3, 539-64. 


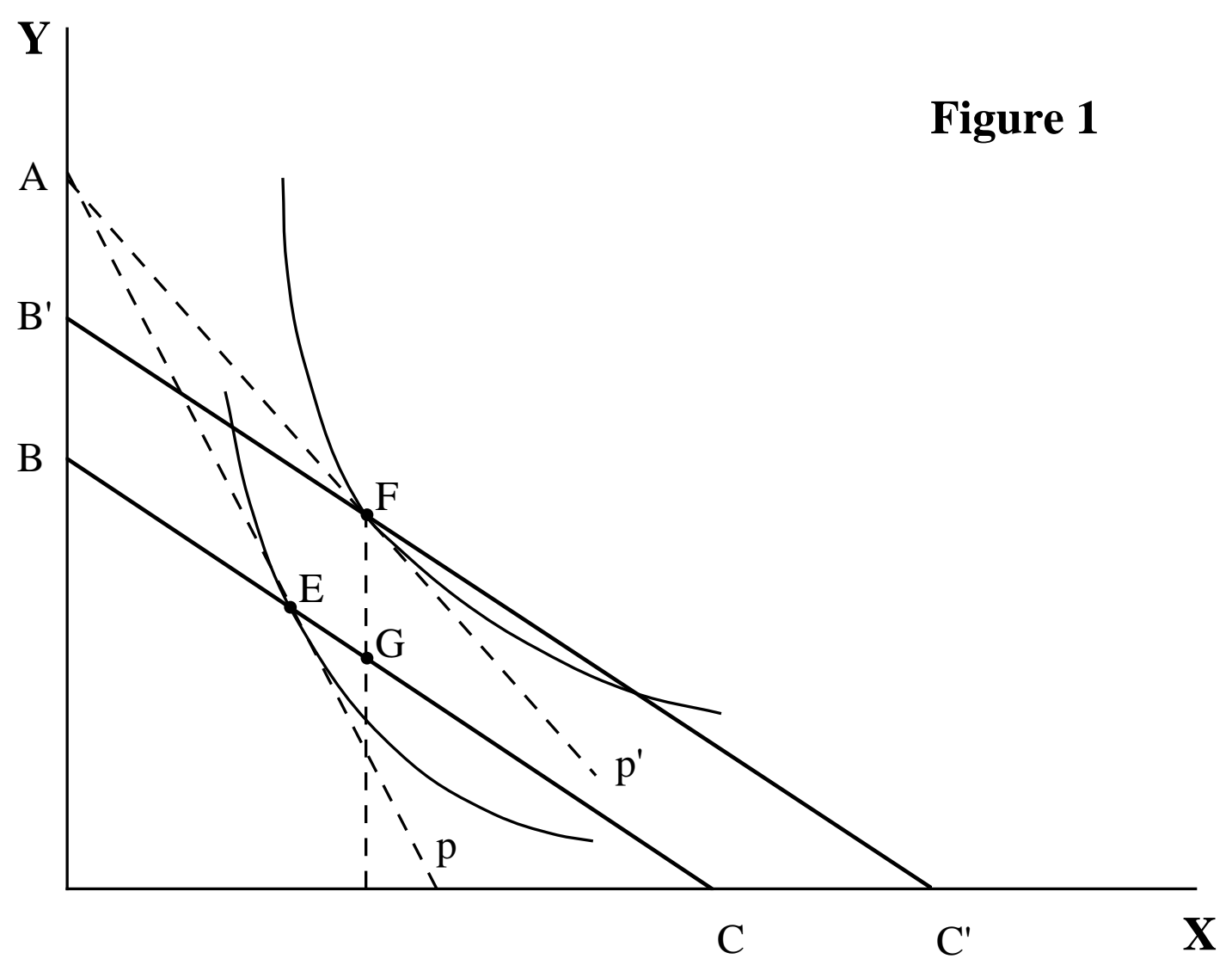




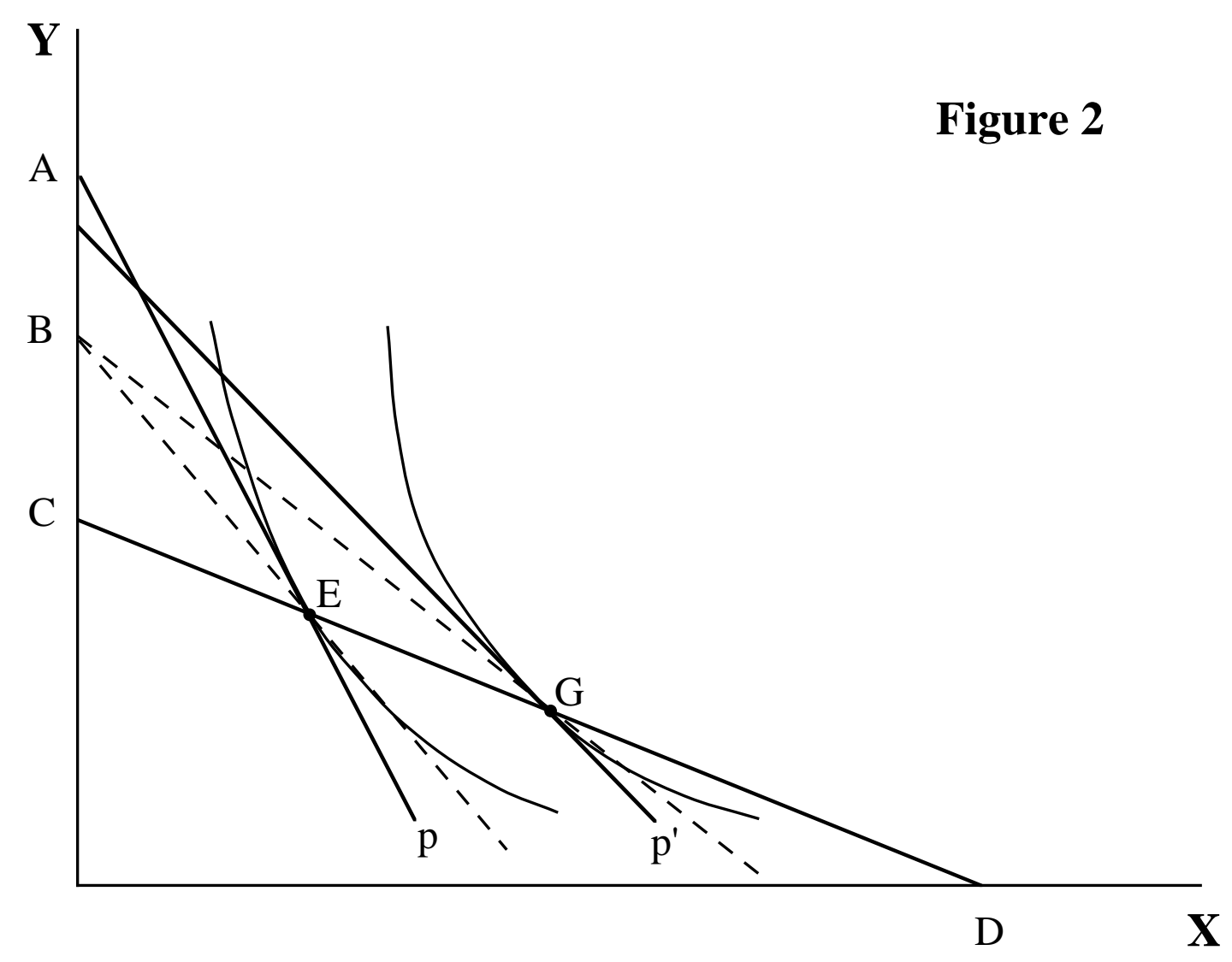


Table 1: Sectoral Disaggregation and Industry Characteristics

\begin{tabular}{|c|c|c|c|c|}
\hline \multicolumn{2}{|l|}{ Sectors } & \multirow{2}{*}{$\frac{\text { Competitive? }}{\text { Yes }}$} & \multirow{2}{*}{$\begin{array}{c}\text { Substitution } \\
\text { Elasticities } \\
2\end{array}$} & \multirow{2}{*}{$\begin{array}{c}\begin{array}{c}\text { Industry } \\
\text { Concentration }\end{array} \\
-\end{array}$} \\
\hline Agriculture and primary products & (SITC: $2,3,4$ ) & & & \\
\hline Food, beverage and tobacco & (SITC: 1,0 ) & Yes & 2 & - \\
\hline Pharmaceutical products & (SITC: 54; Nace-clio: 257) & No & 5 & Low \\
\hline Chemistry other than pharma. products & (SITC: $5-54)$ & No & 5 & Low \\
\hline Motor vehicles & (SITC: 78; Nace-clio: 350) & No & 10 & High \\
\hline Office machinery & (SITC: $75 ;$ Nace-clio: 330 ) & No & 10 & High \\
\hline Other machinery and transport materials & (SITC: $7-78-75$ ) & No & 7 & Low \\
\hline $\begin{array}{l}\text { Other manufacturing industries } \\
\text { (textile, wood, paper, metallurgy, minerals) }\end{array}$ & (SITC: $6,8,9$ ) & Yes & 4 & - \\
\hline Transport and services & Nontraded & Yes & - & - \\
\hline
\end{tabular}




\begin{tabular}{|c|c|c|c|c|c|}
\hline \multirow[b]{2}{*}{$G B$} & Pharmacy & Chemistry & $\begin{array}{c}\text { Motor } \\
\text { vehicles }\end{array}$ & $\begin{array}{c}\text { Office } \\
\text { machinery }\end{array}$ & $\begin{array}{l}\text { Other mach. } \\
\text { \& transp. } \\
\text { material }\end{array}$ \\
\hline & 0.934 & 0.864 & 0.872 & 0.955 & 0.917 \\
\hline$G$ & 0.917 & 0.920 & 0.910 & 0.962 & 0.953 \\
\hline$F r$ & 0.796 & 0.799 & 0.904 & 0.932 & 0.956 \\
\hline It & 0.811 & 0.827 & 0.886 & 0.971 & 0.926 \\
\hline$R E$ & 0.906 & 0.837 & 0.807 & 0.887 & 0.856 \\
\hline$R O W$ & 0.958 & 0.950 & 0.981 & 0.964 & 0.963 \\
\hline
\end{tabular}

Table 3: Calibrated Sunk Costs as Percentage of Representative Firm's Sales

\begin{tabular}{|c|c|c|c|c|c|}
\hline & Pharmacy & Chemistry & $\begin{array}{c}\text { Motor } \\
\text { vehicles }\end{array}$ & $\begin{array}{c}\text { Office } \\
\text { machinery }\end{array}$ & $\begin{array}{c}\text { Other mach. } \\
\text { \& transp. } \\
\text { material }\end{array}$ \\
\hline$G B$ & 0.153 & 0.241 & 0.244 & 0.230 & 0.208 \\
\hline$G$ & 0.195 & 0.133 & 0.164 & 0.190 & 0.114 \\
\hline$F r$ & 0.544 & 0.386 & 0.177 & 0.353 & 0.106 \\
\hline It & 0.501 & 0.320 & 0.213 & 0.146 & 0.184 \\
\hline$R E$ & 0.224 & 0.299 & 0.396 & 0.486 & 0.384 \\
\hline$R O W$ & 0.167 & 0.159 & 0.193 & 0.077 & 0.111 \\
\hline
\end{tabular}




\begin{tabular}{|c|c|c|c|c|c|c|c|}
\hline a. Without Sunk Costs & $G B$ & $G$ & Fr & It & $R E$ & $\begin{array}{c}\text { Aggregate } \\
E E C\end{array}$ & $R O W$ \\
\hline Welfare (Equiv.var.) & 0.45 & 0.16 & 0.35 & 0.57 & 0.17 & - & -0.01 \\
\hline \multicolumn{8}{|l|}{ Number of firms } \\
\hline Pharmaceutics & -2.55 & 0.57 & -0.73 & -0.95 & -2.37 & - & -0.04 \\
\hline Chemicals (nonpharm.) & 0.06 & 0.72 & -0.29 & -0.05 & -0.92 & - & -0.10 \\
\hline Motor vehicles & 2.44 & -11.30 & 2.93 & 8.79 & 17.91 & - & -0.22 \\
\hline Office machinery & -7.80 & -7.21 & -15.15 & -16.73 & -5.20 & - & 0.07 \\
\hline Other mach. \& transp. & -0.15 & 0.92 & -0.83 & -0.72 & -2.21 & - & -0.19 \\
\hline \multicolumn{8}{|l|}{ Efficiency gains (\%) } \\
\hline Pharmaceutics & 1.34 & 0.74 & 0.39 & 0.50 & 0.54 & 0.70 & $-1 . E-3$ \\
\hline Chemicals (nonpharm.) & 0.28 & 0.29 & 0.12 & 0.17 & 0.11 & 0.19 & $-2 . E-3$ \\
\hline Motor vehicles & 10.76 & 1.29 & -1.66 & 2.95 & 1.60 & 2.67 & -0.41 \\
\hline Office machinery & 3.09 & 3.19 & 3.85 & 10.21 & 1.36 & 4.04 & $-2 . E-3$ \\
\hline Other mach. \& transp. & 0.39 & 0.20 & 0.47 & 0.53 & 0.24 & 0.35 & -0.01 \\
\hline All sectors & 1.77 & 0.53 & 0.12 & 1.04 & 0.37 & - & -0.08 \\
\hline b. With Sunk Costs & $G B$ & $G$ & Fr & It & $R E$ & $\begin{array}{c}\text { Aggregate } \\
\text { EEC }\end{array}$ & ROW \\
\hline Welfare (Equiv.var.) & 0.46 & 0.15 & 0.38 & 0.65 & 0.13 & - & -0.01 \\
\hline \multicolumn{8}{|l|}{ Number of firms } \\
\hline Pharmaceutics & 0.00 & 0.00 & -1.48 & 0.00 & 0.00 & - & 0.00 \\
\hline Chemicals (nonpharm.) & 0.00 & 0.39 & -0.24 & 0.00 & 0.00 & - & 0.00 \\
\hline Motor vehicles & 0.00 & 0.00 & 0.00 & 0.00 & 0.00 & - & 0.00 \\
\hline Office machinery & 0.00 & 0.00 & 0.00 & 0.00 & -21.43 & - & 0.00 \\
\hline Other mach. \& transp. & 0.00 & 0.00 & 0.00 & 0.00 & -1.17 & - & 0.00 \\
\hline \multicolumn{8}{|l|}{ Efficiency gains (\%) } \\
\hline Pharmaceutics & 0.08 & 0.19 & 0.53 & 0.25 & 0.06 & 0.21 & $-3 . E-3$ \\
\hline Chemicals (nonpharm.) & 0.16 & 0.11 & 0.12 & 0.16 & 0.02 & 0.11 & $-5 . E-3$ \\
\hline Motor vehicles & 3.94 & -0.54 & -0.07 & 1.51 & 2.77 & 0.95 & -0.03 \\
\hline Office machinery & 0.40 & 0.39 & 0.36 & 0.61 & 1.90 & 0.58 & -0.05 \\
\hline Other mach. \& transp. & 0.14 & 0.12 & 0.09 & 0.14 & 0.21 & 0.13 & -0.01 \\
\hline All sectors & 0.61 & 7.E-3 & 0.09 & 0.34 & 0.41 & - & -0.01 \\
\hline
\end{tabular}




\begin{tabular}{|c|c|c|c|c|c|c|}
\hline \multicolumn{7}{|c|}{$\begin{array}{c}\text { Table 5: Effects of European Trade Integration With Tacit Collusion } \\
(\% \text { deviations from the initial equilibrium) }\end{array}$} \\
\hline With Sunk Costs & $G B$ & $\underline{G}$ & Fr & It & $R E$ & ROW \\
\hline \multirow{2}{*}{$\begin{array}{l}\text { Welfare (Equiv.var.) } \\
\text { Collusion index }\end{array}$} & 0.23 & -0.01 & 0.18 & 0.31 & 0.05 & 0.01 \\
\hline & & & & & & \\
\hline \multirow{2}{*}{$\begin{array}{r}\text { Pharmaceutics } \\
\text { Chemicals (nonpharm.) }\end{array}$} & 0.022 & 0.022 & 0.022 & 0.022 & 0.022 & 0.000 \\
\hline & 0.002 & 0.002 & 0.002 & 0.002 & 0.002 & 0.000 \\
\hline Motor vehicles & 0.164 & 0.164 & 0.164 & 0.164 & 0.164 & 0.000 \\
\hline Office machinery & 0.281 & 0.281 & 0.281 & 0.281 & 0.281 & 0.000 \\
\hline Other mach. \& transp. & 0.010 & 0.010 & 0.010 & 0.010 & 0.010 & 0.000 \\
\hline \multicolumn{7}{|l|}{ Number of firms } \\
\hline Pharmaceutics & 0.00 & 0.00 & -1.48 & 0.00 & 0.00 & 0.34 \\
\hline Chemicals (nonpharm.) & 0.00 & 0.00 & -0.47 & 0.00 & 0.00 & 0.00 \\
\hline Motor vehicles & 0.00 & 0.00 & 0.00 & 0.00 & 0.00 & 0.00 \\
\hline Office machinery & 0.00 & 0.00 & 0.00 & 0.00 & -21.43 & 4.29 \\
\hline \multirow{2}{*}{$\begin{array}{l}\text { Other mach. \& transp. } \\
\text { Efficiency gains }(\%)\end{array}$} & 0.00 & 0.00 & 0.00 & 0.00 & -1.56 & -0.05 \\
\hline & \multicolumn{6}{|c|}{ Efficiency gains (\%) } \\
\hline Pharmaceutics & -0.02 & 0.07 & 0.23 & 0.01 & -0.02 & -0.02 \\
\hline Chemicals (nonpharm.) & 0.05 & 0.06 & 0.07 & 0.04 & -0.01 & -0.00 \\
\hline Motor vehicles & 2.35 & -1.35 & -1.31 & -0.04 & 1.87 & -0.01 \\
\hline Office machinery & -0.18 & -0.10 & -0.92 & 0.10 & 1.15 & -0.30 \\
\hline Other mach. \& transp. & -0.05 & 0.03 & 0.01 & -0.08 & 0.13 & 0.00 \\
\hline All sectors & 0.27 & -0.22 & -0.15 & -0.02 & 0.25 & -0.01 \\
\hline
\end{tabular}

Table 6: Welfare gains: Sensitivity Analysis with respect to Product Differentiation Elasticities $\sigma_{s}$ (\% equivalent variations from initial equilibrium)

\begin{tabular}{|c|c|c|c|c|c|c|}
\hline & $\overline{G B}$ & $G$ & $F r$ & It & $R E$ & ROW \\
\hline \multicolumn{7}{|l|}{ Without Collusion } \\
\hline $0.70 \sigma_{s}$ & 0.46 & 0.19 & 0.42 & 0.66 & 0.09 & -0.01 \\
\hline $1.00 \sigma_{s}$ & 0.46 & 0.15 & 0.38 & 0.65 & 0.13 & -0.01 \\
\hline $1.30 \sigma_{s}$ & 0.46 & 0.14 & 0.38 & 0.58 & 0.16 & -0.01 \\
\hline \multicolumn{7}{|l|}{ With Collusion } \\
\hline $0.70 \sigma_{s}$ & -0.16 & -0.43 & -0.06 & -0.15 & -0.05 & 0.47 \\
\hline $1.00 \sigma_{s}$ & 0.23 & -0.01 & 0.18 & 0.31 & 0.05 & 0.01 \\
\hline $1.30 \sigma_{s}$ & 0.37 & 0.07 & 0.33 & 0.46 & 0.12 & 0.00 \\
\hline
\end{tabular}

